\title{
Idea smart city a przeciwdzialanie degradacji miast
}

\author{
Natalia Gorgol \\ Doktorantka w A-33 - Zakładzie Przestrzeni Urbanistycznych, \\ Wydziat Architektury, Politechnika Krakowska, e-mail:n.gorgol@gmail.com
}

Streszczenie: Każde kolejne pokolenie żyje w coraz szybszym tempie, dlatego również miasta podlegają coraz szybszym procesom transformacji. Stoją one przed coraz trudniejszymi wyzwaniami zarówno ze względu na ilość, jak i tempo zachodzenia w nich procesów transformacji (takich jak m.in. wysoki wskaźnik emigracji, utrata konkurencyjności, degradacja przestrzeni miejskiej i środowiska). Bez wprowadzenia zintegrowanych programów przeciwdziałających degradacji miast, poprawa jakości życia mieszkańców oraz przestrzeni miejskiej zdają się być niemożliwe. Podejmuje się wiele prób mających na celu znalezienie „remedium” dla współczesnych miast. Na popularności zyskuje idea Smart City, wprowadzana w coraz większej ilości ośrodków w Europie. Smart city to miasto inteligentne, czyli takie, które wykorzystuje postęp technologiczny „w służbie” mieszkańcom. Jednym z najważniejszych aspektów smart cities jest synergia wielu elementów składających się na obraz miasta: uwarunkowań społecznych, kulturowych i administracyjnych, gospodarki, warunków mieszkaniowych, inteligentnych technologii oraz inteligentnego transportu. Powiązanie ze sobą wszystkich tych czynników umożliwia efektywny, trwały i zrównoważony rozwój danego ośrodka. Dzięki ,inteligentnemu” zarządzaniu przestrzeniami publicznymi, infrastrukturą i transportem oraz świadomemu społeczeństwu Smart City umożliwia wzrost konkurencyjności miejscowości w poszanowaniu standardu życia jego mieszkańców oraz środowiska naturalnego. Artykuł stawia pytanie o metody wdrażania idei smart city, jako najbardziej efektywnego procesu transformacji współczesnych miast na przykładzie trzech miast: Wiednia, Zurychu i Krakowa.

Słowa kluczowe: smart city, miasto, wymiary smart city, forma miasta, zrównoważony rozwój, strategia Zurich 2035, inteligentne zarządzanie przestrzenią miasta, EU smart cities, Aspern Urban Innovation.

\section{Wstęp}

Żyjemy w coraz bardziej dynamicznej rzeczywistości, dlatego także miasta, jako środowisko naszego życia ulegają coraz szybszym procesom transformacji ze względu na dynamikę zmian. Stoją one przed coraz trudniejszymi wyzwaniami zarówno ze względu na ilość, jak i tempo zachodzenia w nich procesów transformacji. Można wymienić trzy podstawowe płaszczyzny, przyczyniające się do degradacji miast: degradację społeczną, degradację ekonomiczną, degradację przestrzenną. ${ }^{1}$ Bez wprowadzenia zintegrowanych programów przeciwdziałających degradacji miast:, poprawa jakości życia mieszkańców oraz przestrzeni miejskiej zdają się być niemożliwe. Zmieniają się nie tylko potrzeby mieszkańców, ale również ich liczba. O rosnącej roli miast i stawianych im wymagań świadczy chociażby raport Międzynarodowej Organizacja ds. Migracji (IOM), według którego w 2014 na świecie miasta zamieszkiwało 54\% populacji. Zgodnie z raportem liczba

\footnotetext{
Zborowski, 2009.
} 
ludności na świecie w 2050 roku podwoi się i będzie wynosić 6.9 miliarda ludzi. ${ }^{2}$ Prognoza ta pokazuje, jak ważne jest poszukiwanie nowych kierunków rozwoju miast i przeciwdziałania ich degradacji.

Nie sposób prowadzić rozważań nad próbami zachowania konkurencyjności i utrzymania wysokiego poziomu życia w mieście bez wcześniejszego zdefiniowania, czym miasto właściwie jest. Miasto zostało określone w licznych definicjach, podkreślających dany aspekt miasta: terytorialny, historyczny, fizyczny, czy społeczny. Na potrzeby artykułu autor przyjmuje definicję A.Wallisa akcentującą zarówno aspekt urbanistyczny, społeczny jak i tożsamościowy miast, według którego „miasto jest systemem złożonym z dwóch organicznie powiązanych, współdziałających na zasadzie sprzężeń zwrotnych, lecz autonomicznych podsystemów - urbanistycznego i społecznego."3 Na podsystem urbanistyczny składają się materialne elementy antropomorficzne oraz elementy naturalne, które wspólnie tworzą strukturę przestrzenną. Natomiast podsystem społeczny to ,zbiorowość użytkowników miasta." ${ }^{4}$ Nie można zatem rozpatrywać miasta w kontekście materialnych elementów tworzących je, takich jak: system komunikacyjny, założenia urbanistyczne i konkretne budynki w oderwaniu od analizy społeczności, która go zamieszkuje. Miasto jest zatem na tyle dynamiczne na ile zmienne są potrzeby jego mieszkańców. Na potwierdzenie tej tezy warto przytoczyć definicję S. Kostofa, akcentującą dynamiczny charakter miast : „Miasta nigdy nie są spokojne; nie ustają w wysiłkach, aby dokładnie określać swój sens. (...) Pomiędzy konserwacją a procesem to proces musi mieć ostatnie słowo. Ostatecznie urbanistyczna prawda leży w przepływie.” ${ }^{, 5}$ A. A. Kantarek podkreśla w swojej monografii O orientacji w przestrzeni, że budowanie formy urbanistycznej nie może być dążeniem do stworzenia nowej, oderwanej od tożsamości danego ośrodka, wizji miasta, a jedynie procesem dopasowania go do nowych wymagań, co określa jako „przeprowadzenie miasta przez kolejny etap ,podróży.” Należy podkreślić, że niezależnie od podjętych środków przebudowy miasta, ma ona na celu przede wszystkim jak najdoskonalsze spełnienie wymagań i potrzeb jego mieszkańców.

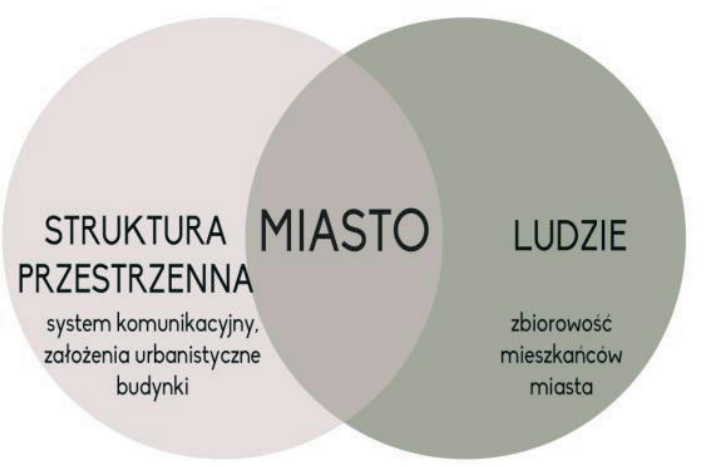

Rys. 1. Graficzne przedstawienie definicji miasta A. Wallisa. Źródło: Opracowanie własne autora

Prowadząc rozważania na temat wymagań i potrzeb mieszkańców jako punkt wyjściowy należałoby przyjąć potrzeby ujęte w piramidzie opracowanej przez A. Maslowa.

\footnotetext{
2 World Migration Report 2015.

3 Wallis 1977 , s.79.

4 Ibidem. Definicję miasta obrazuje grafika (Rys.1) zamieszczona na końcu opracowania.

5 Kostof 1992, [w:] [Kantarek, 2013, s. 21].

${ }^{6}$ Kantarek 2013 s.157.
} 
Poszczególne szczeble piramidy, odnoszące się do potrzeb jednostki można w ujęciu szerszym odnieść do potrzeb danej społeczności miasta. Schemat zamieszczono poniżej Rys. 2.

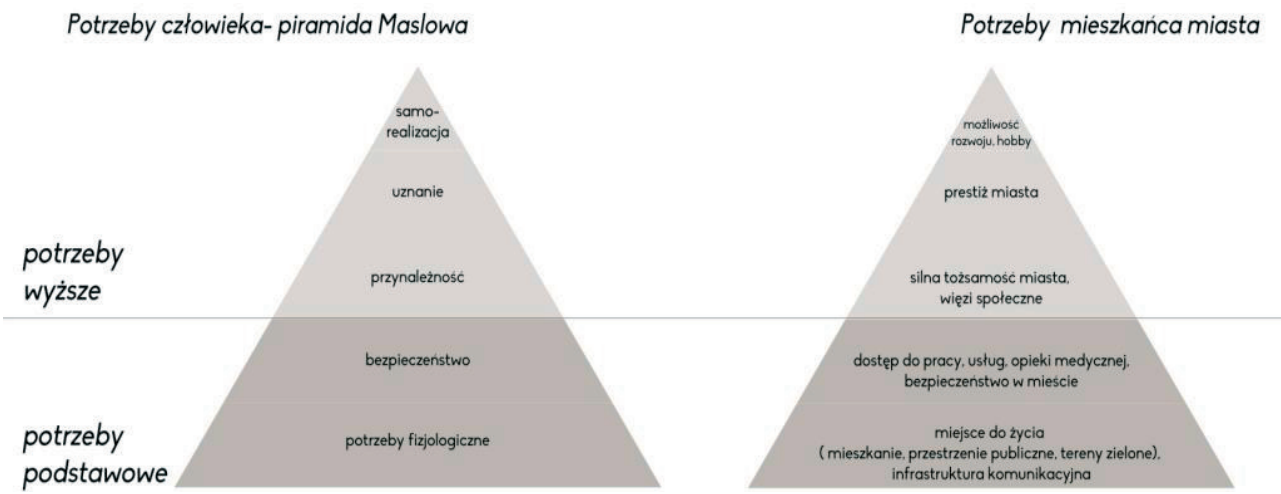

Rys. 2. Graficzne porównanie potrzeb mieszkańca miasta do potrzeb jednostki na podstawie piramidy A. Maslowa. Źródło: Opracowanie własne autora

\section{Idea smart city}

Podejmowane jest wiele prób mających na celu znalezienie „remedium” dla współczesnych miast. Na popularności wyraźnie zyskuje idea smart city, wprowadzana w coraz większej ilości ośrodków w Europie ${ }^{7}$, w tym w miastach średniej wielkości. Według analityków organizacji RAND: 51\% miast Unii Europejskiej o liczbie mieszkańców większej niż 100000 wdraża co najmniej dwa programy, opierające się na idei smart city. ${ }^{8}$ Mimo to trudno wskazać jest jednoznaczną definicję, czym właściwie smart city jest. Przyczyną może być fakt, że większość programów dotyczących stworzenia miasta inteligentnego pozostaje $\mathrm{w}$ trakcie realizacji, a każdy z nich przyjmuje inny aspekt smart city za wiodący.

Podczas poszukiwania znaczenia terminu smart city można natrafić na liczne definicje. Jedne $\mathrm{z}$ nich akcentują technologiczny aspekt miasta oraz wdrażanie rozwiązań opartych na zaawansowanych technologiach, inne skupiają się na elementach tworzących całokształt miasta i uwzględniają także jego mieszkańców. Na potrzeby artykułu przyjęto definicję A.Caragliu, C.Del Bo, P.Nijkampa: „Miasto może być uznane za inteligentne, kiedy inwestuje w kapitał ludzki i społeczny oraz tradycyjną (transport) i nowoczesną (ICT) infrastrukturę komunikacyjną, wspiera zrównoważony rozwój ekonomiczny oraz wysoką jakość życia mieszkańców, przy zrównoważonym zarządzaniu zasobami naturalnymi, przy zaangażowaniu i partycypacji mieszkańców"9

Jako uzupełnienie warto przytoczyć definicję zespołu badawczego pod kierunkiem R.Giffingera prowadzącego badania nad europejskimi miastami inteligentnymi na Uniwersytecie Technicznym w Wiedniu. Naukowcy ci opisującą smart city na zasadzie synergii sześciu elementów składających się na nie: smart economy, smart people, smart governan-

\footnotetext{
7 EU smart cities.

${ }^{8}$ Manville et al., 2014, s.10. Według raportu: Ponad dwie trzecie badanych projektów, prowadzonych na terenie Unii Europejskiej pozostawało w fazie projektowej lub pilotażowej. (Stan na 2014 r.).

9 Caragliu A., Del Bo C., Nijkamp P., 2009.
} 
ce, smart mobility, smart environment, smart living. ${ }^{10} \mathrm{Z}$ urbanistycznego punktu widzenia najistotniejsze są cztery ostatnie składowe. Inteligentne zarządzanie opiera się głównie na partycypacji międzysektorowej oraz planowaniu perspektywicznym. Inteligentna mobilność na zapewnieniu dostępności do danego ośrodka oraz na zrównoważonym, ekologicznym i bezpiecznym transporcie. Na cechy smart living składają się: bezpieczeństwo, jakość zabudowy, atrakcyjność turystyczna miasta, brak wyraźnych różnic społecznych, dostęp do obiektów kulturalnych oraz edukacyjnych oraz opieki zdrowotnej. Inteligentne środowisko to podejście proekologiczne oraz atrakcyjność otoczenia mieszkańca danego miasta.

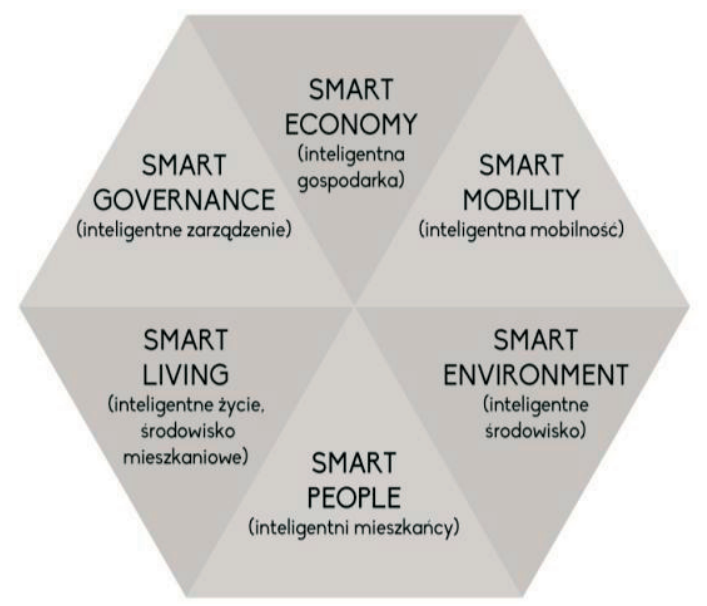

Rys. 3. Graficzne przedstawienie definicji smart city R.Giffingera. Źródło: Opracowanie własne autora

\section{Sposoby przeciwdziałania degradacji miast w odniesieniu do smart city- studium przypadków}

H. Van Beurden określiła trzy elementy potrzebne do stworzenia smart city: wizję, określającą, w jakim kierunku miasto powinno się rozwijać; ludzi, którym miasto ma służyć i respektować ich potrzeby; oraz proces- sposób, w jaki ta przemiana jest możliwa. ${ }^{11}$ Analiza przykładów realizacji wdrażania idei smart city w trzech miastach: Wiedniu, Zurychu i Krakowie opiera się na analizie tych miast na podstawie wyżej wymienionych elementów.

\subsection{Studium przypadku: Wiedeń - przykład dobrze prosperującego europejskiego miasta smart city}

WIZJA

Wiedeń od lat znajduje się w czołówce najlepszych miast do życia, co potwierdzają wysokie noty w rankingach, m.in. druga pozycja, zaraz po Melbourne, w rankingu najlepszych miast do życia na świecie według raportu ośrodka badawczego Economist Intelligence Unit (EIU) na rok 2015. ${ }^{12}$ Mimo że miasto rozwija się harmonijnie i zapewnia mieszkańcom wysoką jakość życia nie ustaje ono w wysiłkach poprawy swojej kondycji. Celem wdrażania idei smart city w Wiedniu jest utrzymanie, a nawet polepszenie, poziomu jakości

10 Giffinger R. et al., 2007 s.11.

11 Van Beurden [w:] Manville et al., 2014, s.78.

12 Global Liveability Ranking 2015. 
przestrzeni miejskiej, środowiska naturalnego i poziomu życia w mieście przy równoczesnym wzroście liczby mieszkańców. Miasto prowadzi też badania nad optymalnymi osiedlami przyszłości na przykładzie projektowanych dzielnic, o czym świadczy przykład nowej dzielnicy Wiednia - Aspern.

\section{LUDZIE}

Zgodnie z założeniami idei smart city proces wdrażania ,inteligentnych” rozwiązań powinien odbywać się na zasadzie partycypacji społecznej. Wiedeń jest przykładem dobrej praktyki w tym wymiarze. Partycypacja przy tworzeniu nowej formy miasta oparta jest na współpracy trzech stron: urzędu miasta, prywatnych właścicieli gruntów oraz instytutów badawczych, których wspólnym celem jest zapewnienie optymalnej przestrzeni życia dla mieszkańców. Współpracę międzysektorową wyraźnie widać na przykładzie dzielnicy Aspern, której masterplan oraz projekt urbanistyczny powstał jako efekt konsultacji społecznych z mieszkańcami, władzami miasta i inwestorami. Mieszkańcy uczestniczą także w procesie realizacji założeń planu poprzez tzw. „City Labs.”

\section{PROCES}

Miasto inwestuje we wszystkie elementy składowe miasta inteligentnego, opisane we wcześniejszej części artykułu, wyznaczone przez zespół badawczy pod kierunkiem R. Giffingera. Jednak w procesie ,podróży miasta” w kierunku smart city szczególne znaczenie mają trzy składowe: inteligentna mobilność (smart mobility), inteligentne środowisko (smart environment) oraz inteligentne życie oraz środowisko mieszkaniowe (smart living).

W kontekście inteligentnej mobilności, celem Wiednia jest redukcja ruchu kołowego indywidualnych kierowców z obecnego poziomu $28 \%$ do $15 \%$ do 2030 roku. ${ }^{13}$ Miasto zamierza osiągnąć ten efekt poprzez dalsze inwestycje w obecnie już dobrze rozwiniętą sieć transportu miejskiego, np. poprzez rozbudowę linii metra pomiędzy nową dzielnicą Aspern a centrum miasta. Planuje się, że eko-mobilność miasta (transport rowerowy, zbiorowy i pieszy, car sharing) do roku 2025 osiągnie pułap 85\%. Dla porównania w 2012 r. udział ten wynosił $73 \%$.

Do działań w ramach polityki smart environment zaliczyć można zarówno priorytetową rolę eko-mobilności oraz wymóg zachowania terenów biologicznie czynnych W mieście na poziomie powyżej $50 \%$ całej powierzchni ${ }^{14}$, który czyni Wiedeń jednym z najbardziej zielonych miast Europy.

Analizując działania w obszarze smart living należy podkreślić, że głównym inwestorem i właścicielem gruntów jest miasto oraz fakt, że cały Wiedeń objęty jest miejscowymi planami zagospodarowania przestrzennego. Wiedeńska polityka budowy nowych mieszkań opiera się na systemie, partycypacji miasta $\mathrm{w}$ procesie budowlanym. W efekcie $60 \%$ populacji miasta ${ }^{15}$ ma możliwość zamieszkania w zabudowie w pełni lub częściowo sfinansowanej przez miasto. Warunkiem dla projektowanej zabudowy jest dostępność finansowa dla mieszkańców. Ponadto, musi ona spełniać następujące warunki: uwzględniać rozwiązania proekologiczne: ograniczać zużycie zasobów naturalnych i emisję CO2 oraz zapewniać wysokie standardy urbanistyczno-architektoniczne.

$\mathrm{Na}$ szczególną uwagę zasługuje proces tworzenia nowej dzielnicy miasta - Aspern, określanej mianem laboratorium innowacji (urban innovation). Zakończenie budowy 240hektarowego, usytuowanego nad jeziorem, osiedla planowane jest na 2028 rok. ${ }^{16}$ Jest to jedno z największych założeń urbanistycznych, realizowanych obecnie w Europie. Projekt

\footnotetext{
13 Rahmenstrategie.

14 Ibidem.

15 Ibidem.

16 Aspern Seestadt.
} 
opiera się na synergii elementów składowych smart city: inteligentnym środowisku mieszkaniowym, inteligentnej mobilności oraz inteligentnemu środowisku, rozumianym także jako wzmocnienie niezależności energetycznej nowej zabudowy. Jest to osiedle modelowe, wyznacznik dla przyszłych inwestycji w Europie w zakresie sposobów ochrony klimatu, redukcji emisji CO2 oraz budowy formy urbanistycznej nowych dzielnic smart cities.

Do najważniejszych wyznaczników wysokiej jakości projektowanego osiedla zaliczyć można:

- dostęp do transportu publicznego i eko-mobilności (Osiedle zlokalizowane jest w regionie CENTROPE, na strategicznej osi rozwoju Wiedeń-Bratysława, który w przyszłości ma stać się wiodącym ośrodkiem badań naukowych. Ponadto, założenie urbanistyczne zostanie powiązanie linią metra z centrum miasta, co zapewni mieszkańcom połączenie z centrum miasta w czasie ok. 25 minut.);

- zróżnicowaną strukturę funkcjonalną nowej zabudowy, w tym zapewnienie równowagi pomiędzy nowymi miejscami pracy oraz udziałem zabudowy mieszkaniowej;

- niezależność energetyczną osiedla oraz planowane zużycie energii na poziomie 2000 Watt na jednego mieszkańca;

- dbałość o jakość rozwiązań architektoniczno-urbanistycznych, zarówno pod kątem estetyki, jak i wykorzystania alternatywnych źródeł energii ( Poszczególne projekty poddawane są szczegółowej weryfikacji przez koordynatorów budowy dzielnicy. Dopiero po spełnieniu podstawowych kryteriów: estetycznych, jakości materiałów budowlanych oraz rozwiązań proekologicznych, projekt zostaje dopuszczony do realizacji.);

- zapewnienie sieci różnorodnych przestrzeni publicznych, w tym dostępu do jeziora i zielonych terenów rekreacyjnych.

\subsection{Studium przypadku: Zurych - przykład przeciwdziałania przyszłej degradacji miast}

WIZJA

Zurych jest miastem o największym potencjale w regionie oraz w całej Szwajcarii. Największy wpływ na rozwój ośrodka miał rozwój banków oraz giełdy zuryskiej, dzięki którym miasto zyskało miano finansowej stolicy kraju. Gospodarczy i finansowy charakter miasta do dzisiaj pozostają jego siłą napędową. Obecnie miasto rozwija się harmonijnie i nie zachodzą w nim alarmujące procesy degradacji. Jednak Zurych, będący miastem średniej wielkości, liczącym ok. 400000 mieszkańców ${ }^{17}$, według prognoz powiększy się o 20\% mieszkańców. ${ }^{18}$ Taka prognoza stawia nowe wyzwania przed miastem. Konieczny jest rozwój miasta i przebudowa jego formy urbanistycznej, aby zapewnić odpowiednie warunki dla stale powiększającej się liczby mieszkańców. Przykład ten jest interesujący ze względu na to, że w mieście został wdrożony proces transformacji, który ma na celu prewencyjne przeciwdziałanie degradacji. Takie podejście nosi niewątpliwie znamiona idei smart city.

\section{LUDZIE}

Strategicznym celem, które miasto postanowiło zrealizować to: równoległa rewitalizacja wielu dzielnic miasta - głównie postindustrialnych, rozbudowa przestrzeni publicznych w mieście oraz wielkoskalarne projekty infrastrukturalne. Zadania te wymagają zmian w obowiązujących przepisach i regulacjach prawnych - opracowania nowych planów

17 Dane za 2014 rok.

18 Strategien Zurich 2035, roz. Wachstum. 
ogólnych rozwoju miasta i danych dzielnic, miejscowych planów zagospodarowania przestrzennego oraz wprowadzenia wyjątkowych przepisów budowlanych oraz planów rozwojowych, pozwalających na skrócenie czasu przebudowy miasta. Przeprowadzanie tych procesów nie byłoby możliwe bez sprawnej i efektywnej komunikacji pomiędzy zaangażowanymi stronami oraz fachowej koordynacji projektów urbanistycznych, architektonicznych i infrastrukturalnych. Dlatego istotną rolę w procesie rozwojowym w kontekście smart city Zurychu ma partycypacja społeczna rozumiana jako współpraca trzech stron: urzędu miasta, prywatnych właścicieli gruntów oraz mieszkańców danej dzielnicy, która miała zagwarantować miastu harmonijny, zrównoważony rozwój.

Ponadto, dla strategicznych stref przebudowy zuryski urząd miasta powołał do życia grupę specjalistów zwaną Gebietsmanagement, działającą w danym, rewitalizowanym obszarze. Grupa ta aktywnie uczestniczy w budowie formy danej dzielnicy, a mówiąc sensu largo, formy miasta, na którą składają się poszczególne dzielnice. Gebietsmanagement koordynuje zarówno fazę projektową jak i budowlaną danej inwestycji. Do zadań grup Gebietsmanagement należą: opracowywanie strategicznych programów, takich jak master plany dzielnicy oraz projekty infrastrukturalne oraz efektywna koordynacja procesu rozwoju danego obszaru i monitorowanie spójności publicznych i prywatnych inwestycji. ${ }^{19}$ Grupa ta jest zaangażowana $\mathrm{w}$ proces rewitalizacji aż do momentu, kiedy konkretne założenia budowlane zostaną zrealizowane.

\section{PROCES}

Od ponad 15 lat zuryski Stadtamt, odpowiednik polskiego Urzędu Miasta, realizuje wraz z właścicielami gruntów i nieruchomości, planistami oraz branżystami zintegrowany program operacyjny. Głównym celem programu jest zapewnienie możliwości stworzenia środowiska życia dla mieszkańców na możliwie najwyższym poziomie, z zachowaniem zasad zrównoważonego rozwoju. Ten miasto rozumie w szerszym kontekście, jako zapewnienie większej niezależności miasta, zarówno w kontekście proekologicznym, prospołecznym oraz urbanistyczno-architektonicznym. Rozwój miasta skupia się zatem na trzech głównych aspektach: potencjale gospodarczym ośrodka, proekologicznym podejściu do zasobów naturalnych oraz aktywizacji wszystkich warstw społeczeństwa. Z architektonicznego punktu widzenia, istotny jest też czwarty dodatkowy aspekt: rozwój w oparciu o poszanowanie urbanistyki i dziedzictwa architektonicznego miasta. ${ }^{20}$

Utworzono trzy programy operacyjne: Strategien Zuerich 2035 (studium kierunków rozwoju miasta), RES (odpowiednik polskiego studium kierunków i uwarunkowań zagospodarowania przestrzennego) oraz BZO (odpowiednik miejscowego planu zagospodarowania przestrzennego), które mają zapewnić ład przestrzenny. ${ }^{21}$ Dokumenty te nie są innowacyjną metodą i można je porównać do Polskich odpowiedników. Główne cele: idea miasta policentrycznego, wysoka jakość życia, rozwinięta komunikacja miejska i infrastruktura oraz bliski dostęp do usług w powiązaniu $\mathrm{z}$ rozwiązaniami urbanistycznymi i architektonicznymi wysokiej jakości też brzmią znajomo. Jednak sposób realizacji tym założeń jest nietypowy i zasługuje na omówienie.

Postulatem wartym uwagi jest polityka dogęszczania tkanki miejskiej, przeciwdziałająca „rozlewaniu się” miasta poza obecne granice. Intensyfikacja zabudowy w tym wypadku nie oznacza spadku jakości życia mieszkańców i utraty przestrzeni biologicznie czynnej, co wpisuje się w podwaliny idei smart city. Dotyczy natomiast rewitalizacji dzielnic poprzemysłowych oraz uwolnienia centrum miasta od nieestetycznej infrastruktury kolejowej

19 Stadt Zuerich- Raeumliche Entwiklungsstrategie.

20 Stadt Zuerich- Planungsinstrumente, Broszura, s.2.

21 Stadt Zuerich- Raeumliche Entwiklungsstrategie. 
poprzez „ukrycie” dworca pod ziemią. Zabieg ten pozwolił na „odzyskanie” 55 ha ${ }^{22}$ powierzchni przeznaczonej pod zabudowę mieszkaniową, biurową oraz usługową. Wymogiem dla projektowanej urbanistyki jest zachowanie zasad zrównoważonego rozwoju, różnorodności zabudowy i policentryczności miasta oraz dbałość o wysoką jakość środowiska naturalnego. Każda z przebudowywanych dzielnic mimo że przechodzi metamorfozę projektowana jest tak, by zachowała swoją indywidualność i wpisywała się w tożsamość miasta. Wymóg ten jest charakterystyczny dla smart cities typu brownfield.

Do innowacyjnych, zastosowanych w Zurychu, instrumentów planistycznych należą: zmiana miejscowych planów zagospodarowania przestrzennego na potrzeby danej strefy przebudowy, wprowadzenie wyjątkowych przepisów budowlanych, znoszących wcześniejsze wytyczne i ograniczenia, nowa parcelacja gruntów, w szczególności terenów o skomplikowanym kształcie, utrudniającym ich zabudowę.

Głównym kierunkiem rozwoju miasta jest zrównoważony rozwój, samowystarczalność energetyczna miasta i redukcja emisji CO2. Miasto systematycznie wdraża politykę społeczeństwa 2000-Watt, które cechuje maksymalne zużycie energii na osobę wynoszące 2000 watt. Na uwagę zasługuje budowa pierwszego niezależnego energetycznie, a więc inteligentnego w kontekście smart city, osiedla Green City o powierzchni 8 ha. ${ }^{23}$ Jest to kompleks biurowo-usługowo-mieszkaniowy, w pełni zasilany energią pochodzącą z paneli fotowoltaicznych, powstały $\mathrm{w}$ procesie rewitalizacji postindustrialnej dzielnicy. Cechą charakterystyczną kompleksu jest też różnorodność mieszkań, od własnościowych po przeznaczone na wynajem. Zurych jest przykładem miasta, które próbuje inteligentnie dopasowywać się do przyszłych potrzeb miasta, by przeciwdziałać degradacji, która jeszcze nie nastąpiła.

\subsection{Studium przypadku: Kraków - polska inicjatywa smart city}

\section{WIZJA}

Kraków jest drugim co do wielkości miastem w Polsce, stale rozwijającym się. W warunkach polskich przyjmuje się, że zdegradowany obszar miejski, to przestrzeń, w której w wyraźny sposób odnotować się da co najmniej trzy z wymienionych poniżej kryteriów: bezrobocie; ubóstwo i trudne warunki mieszkaniowe, przestępczość, niski poziom wykształcenia lub przedsiębiorczości, degradację techniczną, zanieczyszczenie środowiska naturalnego. ${ }^{24}$ Podobnie jak inne duże miasta również Kraków zmaga się z tymi wyzwaniami. Aby polepszyć jakość przestrzeni miejskiej i życia mieszkańców miasto dąży do spełnienia standardów smart city. Proces rozwojowy miasta w kontekście smart city odbywa się na bazie doświadczeń projektów zagranicznych, głównie wiedeńskiego. Podkreślić należy, iż próby wdrażania idei smart city w Krakowie zaczęły się stosunkowo niedawno i mają charakter programu pilotażowego.

\section{LUDZIE}

W pilotażowe projekty dotyczące zastosowania idei smart city w Krakowie zaangażowani zostali specjaliści z wielu dziedzin, pracownicy instytucji administracyjnych (Urzędu Miasta Krakowa, Małopolskiego Urzędu Wojewódzkiego, Urzędu Marszałkowskiego Województwa Małopolskiego oraz Wojewódzkiego Urzędu Pracy) oraz naukowcy zajmujący się problematyką smart city: przedstawiciele Uniwersytetu Technicznego w Wiedniu oraz Forum Virium Helsinki. ${ }^{25}$ Projekt Krakowskiego Parku Technologicznego zakłada

\footnotetext{
2 Stadt Zuerich Europaallee.

Green City.

Miejski program rewitalizacji.

Strategia SMART_KOM 2014, s.6.
} 
wytworzenie partycypacji i współpracy międzysektorowej NBSM (Nauka - Biznes Samorząd - Mieszkańcy). ${ }^{26}$

\section{PROCES}

W Krakowie proces wdrażania „inteligentnych” rozwiązań odbywa się we współpracy z Krakowskim Parkiem Technologicznym Sp. z o.o., która zaowocowała raportem „SMART_KOM Kraków w sieci inteligentnych miast”. Wskazuje on możliwe kierunki rozwoju miasta jako smart city. Określa on także strategiczne wytyczne w sześciu podstawowych aspektach: inteligentnej gospodarki, inteligentnych mieszkańców, inteligentnego środowiska, inteligentnej mobilności, inteligentnego zarządzania i inteligentnego życia. Głównym celem raportu jest zwiększenie świadomości mieszkańców obszaru Krakowskiego Obszaru Metropolitalnego oraz opracowanie strategii rozwoju miasta w kierunku smart oraz możliwych narzędzi, które w tym celu można wykorzystać. Na podstawie tych danych powstała strategia ,SMART_KOM czyli mapa drogowa dla inteligentnych rozwiazań w Krakowskim Obszarze Metropolitalnym”, zawierająca strategiczne rekomendacje oraz omówienie szczegółowe możliwych rozwiązań w obszarach: mobilność i środowisko; partycypacji i jakości przestrzeni publicznej; aktywni, zdrowi i bezpieczni mieszkańcy.

Struktura własnościowa gruntów w Krakowie (przeważająca liczba właścicieli prywatnych) nie pozwala miastu na wprowadzanie wielkoskalarnych inwestycji omówionych na przykładzie Zurychu i Wiednia. Dlatego rozwiązania wprowadzane w mieście mają charakter akupunktularny. Na chwilę obecną rozwiązania typu smart dotyczą inteligentnej mobilności. Jako udane realizacje można wymienić udostępnioną przez Spółkę Miejską Infrastrukturę aplikację mobilną InfoParking, ${ }^{27}$ dotyczącą krakowskiej strefie płatnego parkowania. Informuje ona kierowców o: strefach płatnego parkowania, wskazuje najbliższy parkometr oraz pozwala zapisać lokalizację, w której kierowca pozostawia samochód. Inteligentne rozwiązania zastosowano także w komunikacji publicznej, np.: system dotyczący ruchu tramwajowego oraz system sterowania obszarowego sygnalizacją świetlną. Zarząd Infrastruktury Komunalnej i Transportu w Krakowie wprowadził także miejsca Pocałuj i Jedź (Kiss\&Ride), które pozwalają kierowcom na wysadzenie pasażerów, którzy przesiadają się do środków komunikacji publicznej.

\section{Podsumowanie}

Strukturę przestrzenną miasta i jego mieszkańców można porównać do złożonego systemu naczyń połączonych. Budowa formy miasta jest pracą nad wizją miasta przyszłości i nie może być prowadzona z pominięciem dogłębnej analizy stanu istniejącego, problemów miasta, jego mocnych punktów oraz potrzeb jego mieszkańców.

Miasto ma zarazem wymiar urbanistyczny oraz społeczny, dlatego przeciwdziałanie degradacji miasta nie może skupiać się jedynie na formalnych elementach budujących je: ulicach, przestrzeniach publicznych i budynkach; musi za nimi podążać poprawa jakości przestrzeni miejskiej z perspektywy jej użytkowników. Proces przebudowy musi podążać za potrzebami mieszkańców i stale podnosić warunki ich życia oraz zapewniać zdrowe środowisko do funkcjonowania w danym ośrodku miejskim.

Tempo zmian demograficznych i rosnąca rola miast wymusza poszukiwanie nowych kierunków ich rozwoju. Smart city zdaje się być najbardziej efektywną metodą zwalczania degradacji miasta, zarówno obecnej, jak i prognozowanej, ponieważ bazuje na synergii elementów składających się jego obraz. Proces tworzenia smart city zaczyna się od wizji

26 Strategia SMART_KOM 2015, s.6.

27 InfoParking 2.0. 
miasta przyszłości, która powinna być długofalowa, ponieważ wdrażanie zmian następuje jako „podróż miasta” w kierunku nowej formy. Wizja ta powinna uwzględniać potrzeby ludzi, którym miast służy. Termin smart city nie oznacza tego samego dla każdego miasta. Jak potwierdzono na przykładzie analizowanych miast, transformacja powinna odbywać się z uwzględnieniem kontekstu urbanistycznego, historycznego i kulturowego. Idea smart city powinna być indywidualnie dopasowana do potrzeb danego ośrodka.

\section{Literatura}

1. Zborowski A. (red.) Demograficzne i spoteczne uwarunkowania rewitalizacji miast w Polsce. Instytut Rozwoju Miast, Tom 5, Kraków 2009.

2. World Migration Report 2015. [w:] International Organization for Migration [dostęp:10.01.2016] https:/www.iom.int/world-migration-report-2015.

3. Wallis A. Miasto i przestrzeń. PWN, Warszawa 1977.

4. Kostof S. The city assembled, the elements of urban form through history. Thames \&Hudson, London 1992.

5. Kantarek A. O orientacji w przestrzeni miasta. Wyd. Politechniki Krakowskiej, Seria architektura, Monografia 424, Kraków 2013.

6. EU smart cities. [w:] Rand Corporation

[dostęp:20.02.2016] http://www.rand.org/randeurope/research/projects/eu-smart-cities.html.

7. Manville C., et al. Mapping smart cities in the EU. Brussels: European Parliament, DirectorateGeneral for Internal Policies, Policy Department A: Economic and Scientific Policy, Jan. 2014 [dostęp:21.02.2016]

http://www.europarl.europa.eu/RegData/etudes/etudes/join/2014/507480/IPOL-

ITRE_ET\%282014\%29507480_EN.pdf.

8. Van Beurden H. Dynamics of smart cities: inspiring views from experts across Europe, Amsterdam 2011.

9. Caragliu A., Del Bo C., Nijkamp P. Smart cities in Europe. 3rd Central European Conference in Regional Science - CERS, 2009.

10. Smart cities - Ranking of European medium-sized cities. Wiedeń: Centre of Regional Science, 2007 [dostęp:15.02.2016]

http://www.smart-cities.eu/download/smart_cities_final_report.pdf.

11. Global Liveability Ranking 2015 [w:] Economist Intelligence Unit [dostęp: 10.01.2016] http://www.eiu.com/public/topical_report.aspx?campaignid=Liveability2015.

12. Rahmenstrategie [w:] Smart city Wien, [dostęp:1.03.2016], https://smartcity.wien.gv.at/site/en/initiative/rahmenstrategie/.

13. Aspern Seestadt [w:] Smart city Wien, [dostęp:1.03.2016], https://smartcity.wien.gv.at/site/en/projekte/bauen-wohnen/aspern-seestadt/.

14. Strategien Zurich 2035 roz. Wachstum [w:] Stadt Zuerich, [dostęp:6.01.2016] https://www.stadt-zuerich.ch/epaper/portal/strategie_2035_output/web/flipviewerxpress.html.

15. Raeumliche Entwiklungsstrategie [w:] Stadt Zuerich, [dostęp:6.01.2016] https://www.stadt-zuerich.ch/hbd/de/index/staedtebau_u_planung/planung/raeumliche_entwicklungsstrategie.html.

16. Flattblatt planungs instrumente [w:] tadt Zuerich, [dostęp:6.01.2016] https://www.stadt-zuerich.ch/hbd/de/index/bewilligungen_und_beratung/beratung/planung/ best_practice_planungsinstrumente.html.

17. Europaallee [w:] Stadt Zuerich, [dostęp:8.01.2016] https://www.stadt-zuerich.ch/hbd/de/index/entwicklungsgebiete/europaallee/kennzahlen.html.

18. Green City. [dostęp:17.01.2016] http://www.greencity.ch/de/areal/.

19. Miejski program rewitalizacji [dostęp:28.02.2016] http://rewitalizacja.krakow.pl/rewitalizacja/7346,artykul,miejski_program_rewitalizacji_krako wa.html.

20. Krakowski Park Technologiczny Sp. z o.o., SMART_KOM Kraków w sieci inteligentnych miast, Krakow 2014. 
21. Krakowski Park Technologiczny Sp. z o.o., SMART_KOM czyli mapa drogowa dla inteligentnych rozwiązań w Krakowskim Obszarze Metropolitalnym Krakow 2015.

22. InfoParking 2.0. [w:] Miejska Infrastruktura, [dostęp:29.02.2016] http://mi.krakow.pl/.

\title{
Smart city idea and alleviation of the cities' degradation
}

\author{
Natalia Gorgol \\ PhD Candidate, A-33 - Department of Urban Spaces, Faculty of Architecture, \\ Cracow University of Technology, e-mail:n.gorgol@gmail.com
}

\begin{abstract}
Every single generation tends to live in more and more hectic pace. This is why cities are also going through transformation processes more rapidly. There are many challenges ahead of the cities, not only due to the number, but also because of the pace of transformation processes, such as: high rate of emigration, loss of the competitiveness of cities, degradation of urban space and environment. Undoubtedly, without any integrated programs undertaken to alleviate symptoms of the degradation of cities, neither the improvement of inhabitants' life quality nor the valuable urban space quality may be provided. There are numerous attempts to find the 'remedy' for contemporary cities. While being applied in a significant number of cities in Europe, the idea of smart city seems to be in the spotlight nowadays. This tendency brings up the question of what the term 'smart city' stands for. A 'smart city' would be compared to an intelligent city -the city which uses technological progress to serve its inhabitants. The most vital aspect of smart city is synergy of six basic factors adding up to the global image of a city: social, administrative and cultural conditioning; economy, living conditions, intelligent technologies and intelligent mobility. The combination of all mentioned above elements enables effective and continued growth of a particular city. Thanks to both intelligent governance of public space, infrastructure and transportation; and high awareness of the society the smart city idea ensures not only competitive but also sustainable growth of a city. The article poses a question of what means should be utilized to implement changes to effectively make a city smart. The article presents the analysis of three cities: Vienna, Zurich and Cracow.
\end{abstract}

Keywords: smart city, smart city dimensions, city, urban form, sustainable growth, Zurich 2035 strategy, intelligent governance of urban space, EU smart cities, Aspern Urban Innovation. 
